\title{
THE CHALLENGE OF HYPOTHERMIA \\ A SIX-PROPOSITION MANIFESTO FOR SM ALL ISLAND TERRITORIES
}

\author{
GODFREY BALDACCHINO
}

\begin{abstract}
Conventional wisdom suggests that small, often island, states are more likely than larger nations to be hard hit by the effects of national disasters, of fluctuations in the global economy, and the political aspirations of world powers. The structural weaknesses they share have been quantified to create a Vulnerability Index. This paper points to what the author sees as flaws in the concept of vulnerability and its application to the weaknesses of small states. In particular he presents evidence that small developing countries have performed no worse than larger countries. He sets out six propositions which explain this paradox and identifies the comparative advantages that small states hold.
\end{abstract}

$\mathbf{I}^{\mathrm{T}}$ T IS ONLY IN THE PAST FEW DECADES that a serious attempt has been made to explore critically the idiosyncrasies of small and island territories. No doubt, this area of research was by definition non-existent until such a category of independent, sovereign states started taking their place on the world's geopolitical map, albeit somewhat late in the epoch of decolonization. Such states have themselves lobbied for, or commissioned, internal and external studies which, within the single case study or comparative framework, investigate specific developmental issues in a small, island milieu-particularly public administration; ${ }^{1}$ economic growth and development; ${ }^{2}$ educational provision $;^{3}$

Godfrey Baldacchino is a sociologist specializing in human resource development issues in small territories. He is a lecturer at the University of Malta. This paper was presented at the international conference on Globalization and Constitutionalism: Challenges to Self-Government and Microstates, Nordic House, Torshavn, Faroe Islands, 26-29 April 1999. The author is grateful to the Government and the University of the Faroe Islands for their invitation to attend the conference requesting him to present this paper, and he also thanks the University of Malta for leave of absence. The author acknowledges that many of the ideas and opinions expressed in this paper have been developed on the basis of his relationship with the Institute of Island Studies at the University of Prince Edward Island, Canada, and, through the Institute, with the North Atlantic Islands Programme (NAIP) and its various institutional and individual contributors. He is particularly grateful to David Milne with whom he has been editing a key publication to emerge soon from the findings of the NAIP. 


\section{THE CHALLENGE OF HYPOTHERMIA}

and tourism. ${ }^{4}$

These forays dovetail with one of the latest trends in the analytic social sciences: precisely to depart from grand, all-embracing explanations of reality and to venture into a more in-depth, interdisciplinary and holistic appreciation of the specific, in a style traditionally associated with anthropology. ${ }^{5}$ This social science was actually ushered in and popularized thanks to the observation of small islander behaviour. ${ }^{6}$ This time, however, these sites are not being visited by virtue of presenting themselves as prototype and convenient social laboratory settings. Rather, the current concern is to consider these as territories harbouring a peculiar compendium of features which usher in a tendency for a particular cluster of behaviour patterns, or 'ecology'.'

Today, there is a fairly modest compendium of literature about small and island territories. Echoing Bray ${ }^{8}$ and Smawfield, ${ }^{9}$ many of these sources however go about these analytic arguments without any specific consideration of the smallness and islandness features; their subject matter just so happened to be small and insular.

\section{A positive or negative ecology}

In other cases, an 'ecology' of the small and insular is recognized. Size and insularity are considered as critical leitmotifs which significantly colour and nuance the fortunes of particular territories. Indeed, the leverage exercised by these geographic attributes to small island behaviour goes so far as to become structurally determining, a self-perpetuating myth, assuming even predictive power.

Once equipped with its own ecology, the small island case becomes typically daubed in positive or negative colour. Within the positive camp, we have the fascination of the small and insular world and its fair share of associated glamour, beauty and mystique. This is today craftily packaged as a tourism product, especially appealing for pleasure seekers from the cold, drab, urbanized, industrialized, polluted, anxiety-prone and repressed metropole.

In sharp contrast, a totally different, extreme perspective has become popular in considering small island territories. Since the US invasion of Grenada in 1983, there has been a sustained international concern with the general vulnerability of such small sites. The initiative, fuelled primarily by the British Commonwealth, found fertile ground both in the vocabulary of micro-state policy makers as well as of mainstream neo-classical economic advisors.

The flagrant intervention into the internal affairs of a small (albeit sovereign) state was apparently the last straw: this was the catalyst which led to a spate of treatises highlighting and exposing powerlessness and dependency. Natural disasters, commodity price fluctuations, the whims of aid donors, tour operators and foreign investors-not to mention the belligerent intentions of larger and stronger neighbours - these were all factors external to the small island site over which it had hardly any influence, let alone the possibility of exercising control. ${ }^{10}$ This decade therefore stands out as the one which discovered that small, often island, sites suffer from vulnerability-an intrinsically negative attribute which has also been subsequently quantified in the guise of a Vulnerability Index. ${ }^{11}$ Couching vulnerability in this way may make ample diplomatic 
sense, especially if weakness and fragility are expected to lure interest, publicity, sympathy and assistance, in cash or in kind.

Of course, there is a strong diplomatic effort behind the vulnerability thesis. Proclaiming structural weakness is an important platform from which to argue for structural aid and assistance. Small island territories, whether independent or otherwise, have been capable at extracting transfers or concessions from abroad in support of such an argument. Small islanders have been the strongest per capita aid beneficiaries in the world. It is likely that this effort will continue, and that it will continue to find sympathy and goodwill from such trading partners who would be willing to offer, or tolerant to suffer, non-reciprocal, bilateral or multilateral, agreements.

\section{Against vulnerability}

There are, however, a number of essential problems with the whole concept of vulnerability and its implications regarding small state weaknesses. I will elaborate on just two of these.

The first is that the very same characteristics which are meant to signify vulnerability are not necessarily handicaps but they can equally well imply a proneness to spectacular growth. The events which demonstrate vulnerability are simply the 'flip-side' events of the development process on the small and insular. To the harbingers of woe must be added the messengers of good fortune whose impact on the micro-insular site would tend to be just as powerful, just as total. The attraction of a major foreign investor; a boom tourist season; clinching a major bilateral deal; securing a niche export market. Both curses and blessings from 'away' come upon the small and insular in a common and distinct manner: with a suddenness of impact, an intensity of effect, and a high speed of penetration and engulfment. We are talking about an economy which, being small and insular, is naturally more 'boom and bust', 'peak and trough' oriented, more spasmodic and jerky than its larger, continental counterparts. ${ }^{12}$ The key explanations for such jerks are often discrete, external events.

Secondly, the vulnerability argument presupposes that the small and island location is a closed system. The ravages of a natural, economic or military event would assume more salience were the victim expected to solve its own problems without any trans-border assistance. In such a case, vulnerability would be a fair description of a most unhappy predicament. But this assumption could not be further from the truth; it would betray an ignorance of the very constitution of many small islands. They have been amongst the most open of societies. Because of the intense and total effect of that external event-colonizationmany small islands have found themselves linked to, and carried piggyback onto, the global network of their administrative overlord. They have been accommodated - at times begrudgingly (as in the case of Britain), at times more enthusiastically (as in the case of France)-onto this circuit in trade, culture, education, employment, language legislation and religious belief. ${ }^{13}$ In these and other aspects, they have thus usurped their small island boundary. No wonder small islanders are disproportionately avid foreign travellers; disproportionately very well represented overseas; disproportionately confident users of international languages; disproportionately keen transnational mercantilists; dis- 
proportionately very active and present in international fora. The converse is also true: given their permeability to such links, these locations and their local inhabitants are also disproportionately high recipients of foreign tourist visitors, foreign consultants, foreign settlers, even foreign spouses.

Sociologically speaking, small islanders often behave as if their small island is the whole world. Yet, it would also be correct to state that, to a large proportion of islanders, the whole world is their island. It is therefore fundamentally incorrect to present small islands as closed systems. Many small islands have never been closed, having rather been discovered and even created by globalizing colonialism. Plugged as they are into the global circuitry, they have transcended the limitations afforded by small physical size and isolation, often coupled by a poor natural resource base. They actually qualify nicely as the world's first, geographically delineated global villages.

\section{A different resourcefulness}

If this criticism of the vulnerability manifesto is at all plausible and valid, then the present decade may perhaps be characterized with the discovery of small island resourcefulness. It is a resourcefulness in part predicated and pushed forward by the absence of exploitable resources of the traditional, neo-classical kind. It is a resourcefulness which confirms that necessity is the mother of invention. It is a resourcefulness which confronts the conventional development paradigm, grounded in the unshaken belief in manufacturing, economies of scale, large populations, natural resources, military strength, and other strands of the 'big is beautiful' theme. It is a resourcefulness ultimately inspired by a stubbornly positive, economic track record. It is such resourcefulness which confronts the woes of hypothermia and transforms them into a different type of economic asset.

Of course, one may find it easier and more secure to stick resolutely to the given paradigm. In such a case, all one can say about the performance phenomenon of small island territories worldwide is that it constitutes some kind of exception, or 'a special case'. ${ }^{14}$ They may argue that the small island experience of economic success is a freak, or 'paradox', of development. ${ }^{15}$ They may assert that such an experience is only the calm before the storm: a temporary spell of good fortune, soon to be overtaken by events.

But how soon is soon? Where is the storm? How long should one wait for it to break and thus confirm the old theory $?^{16}$ Indeed, bigger states as well as smaller territories supposedly in a benign relationship with a larger state have had their own fair share of economic storms. ${ }^{17}$ In the meantime, life goes on and practice calls out loud for some theoretical support.

With the exclusion of Japan and the USA, the world's 10 most populated countries recorded an average GNP per capita of just US\$1100 in 1997; in contrast, the world's 10 least populated countries recorded an equivalent average GNP per capita of US\$3800. ${ }^{18}$ Some 13 per cent of the world's small states are in the lowest income group compared with 37 per cent of the larger states; while 23 per cent of micro-states fall into the highest per capita income bracket, compared with only 17 per cent of larger states. ${ }^{19}$ Even The Economist has been obliged to recognize that not all is doom and gloom about the small, 
insular, remote and forlorn: 'the curse of the periphery is a myth'. ${ }^{20}$

It should prove more instructive, and definitely more useful, to accept that the going paradigm has major loopholes and seek a worthy replacement. It is high time to stop trying to fit the square practices of small island territories into the round holes of conventional wisdom. In this rethinking exercise, space must be allocated even for those 'pseudo-development' strategies of small island territories which are shamelessly parasitic; ${ }^{21}$ or which thrive on the 'marketing of identity'. ${ }^{22}$ Even the Commonwealth Secretariat, a champion of the adverse implications of small size and insularity, has been obliged to confront the facts:

In spite of [alleged small state] constraints, the empirical evidence shows that the economic performance of small developing countries since 1980 has been no worse than that of larger countries-indeed, if anything, slightly better. This suggests that the obstacles mentioned earlier are not so serious or that small developing states found ways of overcoming or compensating for them..$^{23}$

It is with this ambitious project in mind that I invite you to consider the following six principles below as the constitutive, inter-related components of an alternative theory for small island development.

This is not the first time that such an exercise is being done. But the boldness and temerity even to consider such a project is definitely a recent state of mind. Those who tried something similar in the past ${ }^{24}$ did so more out of idealism and wish-fulfilment. Moreover, many of these could only make bland and glib contentions which did not stand up to rigorous testing. ${ }^{25}$ Thirdly, there was no theory available to defend and, more importantly, to explain what was behind small state success. ${ }^{26}$ Like Luigi Pirandello's dramatic piece, Six Characters in Search of an Author, the personalities were there for all to see; but there was yet no author to write their script. ${ }^{27}$

Today, I can calmly and confidently argue for a manifesto of small, often island, states. A script is at last being written for these actors. And it is a script which argues that small is full of surprises. This rendition needs no longer be based on fanciful myths and romanticized images but on hard evidence and proven economic resilience. Today, one can thus claim to be well on the way to presenting a theoretical framework to explain successful small state econom ics. ${ }^{28}$

One key characteristic of the new theoretical architecture is the critical rôle played by system players - the small state citizens themselves - in prejudicing and nuancing their individual and collective economic fortunes. Rather than sticking stubbornly to structuralist and determinist arguments which leave no place for human actors - whether couched in terms of insurmountable vulnerability or euphoric 'small-is-beautiful' platitudes-the new thesis is premised rather on the importance of individuals to realize that they need to, and can, exercise control; that they can put into action 'governing wits' ${ }^{29}$ that they need to, and can, make up handsomely for traditional economic poverty by deploying instead the available resources of legal and policy instruments which, in their turn, result from jurisdictional status.

And this leads to the second key characteristic of the new theory supporting small island development. Our theory of small state survival and prosperity 


\section{THE CHALLENGE OF HYPOTHERMIA}

results from the recognition of the econom ic resourcefulness of rule and policy making.

Perhaps it is the novelty of the approach-novel in the sense of doing away with traditional disciplinary boundaries - that may partly explain why it has taken so long to conceive. In proclaiming that politics is a key economic resource, we are here discounting the rôle of such factors as: the availability of raw material deposits, research and development acumen, technological prowess, domestic materials, even local value added. Instead, we are replacing these with the power to make laws; to offer better incentives to foreign investors; to tap external resources; and to do and change all these, and more, quickly. Hypothermia becomes a challenge-rather than an ailment-when looked upon through the fresh perspective of political economy. ${ }^{30}$

\section{Proposition no 1}

Coming across life-histories of microstate individuals, one finds that these human specimens from Lilliput essentially look at the world as their oyster. Many have spent a stint travelling, working or studying abroad; many survive on the basis of business or trade contacts with foreigners; many have close relatives who have emigrated temporarily or permanently beyond their native shores and therefore for them transnational commuting is necessary to cultivate family bonds and maintain contact. No wonder successful small, often island, territories would easily qualify as being the prototype global villages; their citizens have been all along pioneering global citizens, long before the term was invented. They have often had to plug themselves onto the global economic circuitry out of sheer necessity. For income, emigration or education, they have had to look 'away'. Having no- or not enough-indigenous, economic hinterland to exploit was a very powerful push factor, a material condition of economic 'sub-optimality' which bred a culture of propensity to deploy the foreign card, rendering themselves potentially suitable for eventual dislocation. This includes fluency in languages of international currency (and therefore an outward-oriented educational system); extensive migratory waves; as well as healthy and harmonious international relations with would-be host states. Indeed, very few small states have entertained development strategies which obliged a break of relations with major foreign powers. Keeping the external option open, and cultivating 'transnational corporations of kin' ${ }^{31}$ has been a more significant development variable than any socialist or nationalist arguments about economic self-reliance or independence.

Most small jurisdictions thus also managed to avoid the pitfalls of the tempting protectionist policies entered into by larger developing states. Structural openness, coupled by the small domestic market size, renders non-intervention in trade as the natural, but also optimal, competition policy. ${ }^{32}$ In adopting this route, often out of Hobson's choice, small territories mercifully avoided the productive inefficiencies, market distortions and vested interests which followed in the wake of most import-substituting policies.

In so doing, small islanders, again often unwittingly, also aligned them selves to provide the services and features which are best suited to attract foreign direct investment and other lucrative industries-such as tourist, knowledge- 
based services and offshore finance. They have also been steadily expanding their economic space extra-territorially by building the links with the 'great outside' - through emigration, employment and education- which can eventually be transformed into economic capital. Trade, education, cultural policy in small island territories are influenced by the latter's generalized structural openness and cosmopolitan inclination; this means that these small islands are more favourably disposed towards attracting direct foreign investment as well as to go for export-led growth than are other, larger countries which could be more reliant upon domestic markets and autonomous internal sources of grow th.

\section{Proposition no 2}

Successful small, often island, territories have been obliged to develop and refine ingenious political resourcefulness to assuage the limitations imposed by the classical economic problem of scarcity. Bereft of land, labour, capital, markets or finance, island Lilliputs have been deliberately seeking to maximize domestic, jurisdictional controls; while still seeking to establish external, special or privileged deals and relations with a variety of Gullivers. Indeed, the economic problems of various micro-territories today have much to do with a failure to manage the political agenda both domestically and internationally (see below), in a manner as would provide longer-term, sustainable, econom ic gains.

There is ample evidence that many micro-states have made effective use of optimal endogenous policy-making ... to pursue high growth strategies. ${ }^{33}$ (my emphasis)

Even in relation to the vulnerability thesis, political and administrative autonomy makes sense: since an island is prone to very rapid and unexpected changes, it should be in a position to react accordingly, precisely by enjoying those jurisdictional powers which would enable it to take those required policy measures quickly and effectively. ${ }^{34}$

I must here address an issue which would appear to contradict my hypothesis: the large number of small island territories which have chosen to date not to achieve political independence. Note that I use the word chosen, because many of these territories today enjoy the legal instruments which would enable them to ask for, and obtain, some status on the scale of autonomy which could culminate in full political independence, should they desire it. ${ }^{35}$ The best way to understand this situation is to appreciate how a small state may consider its best bet as free-riding on the laws, resources and clout of a larger player. ${ }^{36}$ Indeed, integration-or 'upside down decolonization' - has been a popular policy instrument with which to confront decolonization for small states. ${ }^{37} \mathrm{~W}$ ith pannational groupings now assuming stronger powers and influence on the global playing field, small territories may decide that their interests are best defended and promoted by establishing direct deals and linkages with the supranational entity, rather than dealing through a big, intermediary state.

Indeed, even politically independent states still ride unperturbed piggy back on the resources, economic or constitutional, of other larger states. Through pseudo-membership of hard currency areas, as well as free-riding on inter- 


\section{THE CHALLENGE OF HYPOTHERMIA}

national defence agreements, these mini-states enjoy an envious fiscal stability and a military defence capability they would find hard put to entertain with their own means. ${ }^{38}$ They also pursue niche strategies with in the international regulatory framework and seek to maximize rent-seeking (as against value added) opportunities. ${ }^{39}$

The key characteristic of political resourcefulness is how it has been deployed into a public policy regime which has in turn proved effective in an economic sense. Such effectiveness often implies the creation of a competitive economic space which attracts foreign players-be they investors, financiers, agents, traders, tourists, but also aid donors and benefactors. The comprehensive competitive advantage of small island territories lies precisely in the deliberate manufacture of this advantage. Being poor, remote, isolated and marginalized has its obvious costs, according to mainstream economic thought. But the very same dross features can craft surprising 'magical' benefits, when the players enjoy the jurisdictional instruments which enable the operation of such a skill. Who said alchemy is dead?

\section{Proposition no 3}

Of course, the possession and utilization of political instruments to adopt such a strategy must be available to the players who would use them. In this, small often island territories have had the double advantage of geographic 'boundedness' and isolation: these physical features have often obliged rulers to treat these territories as distinct administrative units enjoying some measure of autonomy. It is on the basis of such discretion that external (eg international relations; bi- and multilateral trade agreements; lobbying and active participation at $U N$ and other international and regional fora) and internal (eg fiscal regimes; education and training policy; monetary policy; transportation policy; labour law; competition policy; industrial development and environmental policy) powers and initiatives can be entertained in the first place.

What is less obvious in this discussion is that even the small islanders themselves require the vision and perspective to see themselves as a distinct administrative unit. This sense of being must result not only in contrast to the external (often colonial or federal metropolitan) master; ${ }^{40}$ but also in direct reference to one's own identity, as a distinct island community. The cultural image of such an 'island imagination' is a vital component which propels social, political and economic thrusts for development. The same island condition and identity would thus be readily used to justify political, social and economic challenges: in arguing the validity of special treatment by others; in instituting an effective transportation policy; in introducing equalization measures or allowances; in branding tourism products; and, ultimately, in proclaiming specific political demands. $^{41}$

\section{Proposition no 4}

Because they are often islands in a social and administrative-apart from a geographical-sense, ${ }^{42}$ such small territories often enjoy a distinct cultural fabric, history and language which foster a sense of island identity. This coagulator can 
propel 'Microstate plc' as a largely unitary entity - as a people - in its transnational economic and political dealings, providing strong, binding and durable principles which make for social partnership and cooperative labour relations. The insular mind-set acts as a common cultural denominator which colours the manner in which islanders read and respond to external challenges and can somehow override or temper internal social and political divisions. It is a mindset which also maintains strong bonds of loyalty even amongst islanders who, having migrated, are no longer based on their home island.

Certain observers have claimed that small territories are more likely to practice benign politics and to enjoy social cohesiveness. ${ }^{43}$ Such a claim, how ever, appears dubious or otherwise simplistic. ${ }^{44}$ It is probably naive to declare that the societies of small countries are harmonious because everybody knows everybody else. ${ }^{45}$ On the other hand, it is probably correct to say that small size makes for social compression, stronger personal contacts and wider rôle enlargement, rôle diffusion and rôle multiplicity. ${ }^{46}$ These features in turn make for a particular pattern of human interaction. They facilitate the aggregation of individual into group interests; they offer more effective supervision of group discipline and compliance with any agreements made ${ }^{47}$ strong export dependence makes it more essential to secure moderate wage development and to avoid any labour unrest which might harm productivity and subsequent foreign investment flows; ${ }^{48}$ while jurisdictional agencies are more likely to include interest groups in the formulation and implementation of policy and will thus have vested interests in supporting these associations, especially in following more moderate policies perhaps closer to the interests of the state itself. ${ }^{49}$

In summary, we are therefore confronted with a clannish, 'societal corporatist' variant of the model of pluralism deemed as the hallmark of modern democratic polities: one whose social capital has the potential for durable, consensual and moderate politics. ${ }^{50}$ Is it a coincidence that the oldest and regular democratic institutions in both the western and eastern hemispheres are to be found in small islands? ${ }^{51}$

\section{Proposition no 5}

The potential for durable, consensual and moderate politics in small territories can be accompanied by a second advantage: that of rapid policy development. Once an opportunity presents itself, it should be relatively easier for the microjurisdiction to perform the necessary 'turn-around' to exploit it and maximize its returns. Against a global scenario of turbulence, dynamism and uncertainty, smaller systems are argued to stand a better chance of coping with and surviving rapid changes in their environment than do larger systems. ${ }^{52}$ The vibrant, organic, 'just-in-time' oriented enterprise is more likely to be small. ${ }^{53}$ Most small economies have managed a very rapid, smooth transition from primarily agricultural/plantation to primarily service economies; ${ }^{54}$ while others became manufacturing platforms within a couple of decades. ${ }^{55}$ The dense psychosocial atmosphere, ready association of persons with specific decisionmaking acumen and the intricate rôle networking and rôle multiplicity of actors render policy coordination and the management of change potentially easier and faster. 


\section{THE CHALLENGE OF HYPOTHERMIA}

Such a condition of transparency and personalization of authority structures has been described as resulting in a 'soft state'. ${ }^{56}$ The Head of State of a small territory (or anyone of substance, for that matter) is typically two phone calls away: and such access would be known and available to a substantial chunk of the population. ${ }^{57}$ This condition might work against institution-building; but a lean and identifiable decision-making structure certainly improves on critical, reaction time. This may be a precious policy instrument which helps to balance and complement the more conservative and slow machinations of consensual politics.

\section{Proposition no 6}

Such a macro condition has parallels at industrial, organizational and individual levels. It has to do with economic capacity ${ }^{58}$ - the ability of a people in a jurisdiction (or of economic elites therein) to respond to opportunity and adversity. ${ }^{59}$ While response capability is a behaviour pattern probably synonymous with the human condition, it may nevertheless be diluted or swamped by overtly protectionist or paternalist public policies. Economic capacity can ironically also be weakened by successful political resourcefulness when diplomacy and international relations enable the micro-economy to be 'killed through kindness'. ${ }^{60} \mathrm{It}$ is the capacity of governments, communities, trade unions, employers, firms, households and individual men and women to prove their salt as opportunists, intermediaries and flexible specialists. ${ }^{61}$ This is how they are best disposed to manage 'glocalization' - the inevitable, complex confluence and interplay of the local and the global. ${ }^{62}$

There is a clear synergy and cumulative pattern resulting from these six propositions. Smallness and islandness can provide the geographical stimulus for administrative autonomy; the economic stimulus for a 'political economy' approach to growth, development and prosperity; the cultural stimulus for a unitary, communal identity; and the social fabric to manage all this in a flexible, rapidly reactive manner. This is perhaps the closest we have come to grasp the proper 'ecology' of small islands.

\section{Conclusion: $m$ icroeconom ics interacting with globalization}

Tensions between autonomy and dependence take on new significance for microeconomies in the process of globalization. Given the structural openness of small island territories, the equally structural dependence on 'externalities' is a fact of life. Yet, does such a dependence necessarily imply weaknesses, risks and handicaps? ${ }^{63}$ Yes, but only if we somehow believe that surviving on an externally driven economy is wrong. Only if we are still glibly pursuing the phantom goal of economic self-reliance. Only if we are convinced that exposure results in fatal hypothermia.

Yet, contemporary econom ic history reads differently. Many microeconomies prosper today, precisely by having thrown the economic self-reliance model overboard: it was a model which they could never have taken seriously anyway. ${ }^{64}$ Instead, they have been discovering and crafting a different type of self-reliance, a jurisdictional self-reliance which guarantees the control over the 


\section{THE CHALLENGE OF HYPOTHERMIA}

instruments, and consequently the terms, of economic dependence.

For many small territories, the best road forward appears to include a strengthening of jurisdictional powers with the intention to deploy these in economic directions. The opportunities for such a deployment are more numerous now, given the multiple layers of layered identity, representation and negotiation, ranging from the subnational to the supranational. ${ }^{65}$ Proclaiming vulnerability is one strategic application of such powers, lucrative and viable in its own strange way. ${ }^{66}$ Competing on the global playing field by niching both products and/or services as well as the terms of their trade is another viable strategy. Perhaps the major debate amongst Lilliputs today is whether to go for the former (non-competitive) or the latter (competitive) route; perhaps both routes can be skilfully deployed concurrently. What should not be debated is that the choice of either, or both, of such routes, is best to rest securely in the hands of the small territory.

\section{Notes and references}

1 For example, R. Baker, Public Administration in Small and Island States, Kumarian Press, West Hertford, CT, 1992; Special Issue on the Impact of External Relations in the Domestic Policies and Institutions of Microstates, Public Administration and Development (PAAD), Vol 18, No 2, 1998.

2 E. C. Dommen and P. L. Hein (eds), States, Microstates and Islands, Croom Helm, Beckenham, 1985; D. L. McKee and C. A. Tisdell, Developmental Issues in Small Island Economies, Praeger, New York, 1990.

3 M. Bray, Educational Planning in Small Countries, UNESCO, Paris, 1992; M. Bray and S. Packer, Education in Small States: Concepts, Challenges and Strategies, Pergamon, Oxford, 1993.

4 L. Briguglio, B. H. Archer, J. Jafari and G. Wall (eds), Sustainable Tourism in Small and Island States: Vol 1: Issues, Pinter, London, 1996; D. Lockhart and D. Drakakis-Smith, Island Tourism: Problems and Perspectives, Mansell, London, 1997.

5 E. Laclau, Reflections on the Revolution of Our Time, Verso, London, 1990, p 190; P. Sztompka, 'Conceptual frameworks in comparative enquiry: divergent or convergent?', in M. Albrow and E. King (eds), Globalization, Knowledge \& Society, Sage, London, 1990, pp 45-65, especially p 55.

6 B. Malinowski, Argonauts of the Western Pacific, Routledge, London, 1922; R. Firth, We, the Tikopia: A Sociological Study of Kinship in Primitive Polynesia, Unwin, London, 1936; M. Mead, Coming of Age in Samoa, Penguin, London, 1949 .

7 Commonwealth Secretariat, Educational Development: The Small States of the Commonwealth, report of a pan-Commonwealth Experts Meeting, Mauritius, 1985, Commonwealth Secretariat, London, 1986, p 6.

8 Bray, op cit, Ref 3.

9 D. Smawfield, 'Notions of smallness: What are they and what are their implications?', in K. M. Lillis, (ed), Policy, Planning \& Management of Education in Small States, UNESCO, Paris, 1993, pp 25-47.

10 C. E. Diggines, 'The problem of small states', Round Table, No 295, 1985, pp 191-205; A. Dolman, 'Paradise lost? The past performance and future prospects of small island developing countries', in E. C. Dommen and P. L. Hein (eds), States, Microstates and Islands, Croom Helm, London, 1985, pp 40-69; F. Doumenge, 'The viability of small inter-tropical islands', in E. C. Dommen and 
P. L. Hein (eds), States, Microstates and Islands, Croom Helm, London, 1985, pp 70-118; Commonwealth Consultative Group, Vulnerability: Small States in the Global Society, Commonwealth Secretariat, London, 1985; S. Harden, Small is Dangerous: Micro-States in a Macro-World, Pinter, London, 1985; P. Lyon, Small States and the Commonwealth, Butterworth, London, 1985; P. Bune, 'Vulnerability of small island states: the case of the South Pacific Region', The Courier, No 104, 1987, pp 85-87; C. G. Clarke and A. Payne (eds), Politics, Development \& Security in Small States, Allen \& Unwin, London, 1987.

11 L. Briguglio, 'Small island developing states and their economic vulnerabilities', World Development, Vol 23, No 9, 1995, pp 1615-1632. The Vulnerability Index is composed of three measurable variables, with a respective weighting of 50,40 and 10 per cent: exposure to foreign conditions (measured in terms of ratio of trade to GDP); insularity and remoteness (measured in terms of transport and freight costs in relation to exports); and proneness to natural disasters (measured in terms of the economic costs of such events as recorded by UNDRO data).

12 G. Baldacchino, 'Far better to serve in Heaven than reign in Hell: the logic of Malta's relationship with the EU', in G. Baldacchino and R. Greenwood (eds), Competing Strategies of Socio-Economic Development for Small Islands, Institute of Island Studies, University of Prince Edward Island, Charlottetown, 1998, pp 225-227; S. Carse, 'Sustaining small island development: the Isle of Man', in G. Baldacchino and R. Greenwood (eds), Competing Strategies of SocioEconomic Development for Small Islands, Institute of Island Studies, University of Prince Edward Island, Charlottetown, 1998, pp 268-291, especially p 277.

13 H. M. Hintjens and M. D. D. Newitt (eds), The Political Economy of Small InterTropical Islands: The Importance of being Small, University of Exeter Press, Exeter, 1992.

14 For example, R. Kaplinsky, 'Prospering at the periphery: the special case', in R. Cohen (ed), African Islands and Enclaves, Sage, London, 1983, pp 195-215.

15 For example, G. C. Abbott, 'Small states: the paradox of their existence', in P. Selwyn (ed), Development Policy in Small Countries, Croom Helm, London, 1975 , pp 105-114.

16 This is tantamount to another criticism of the Vulnerability Index, since the methodology behind nits derivation is cross-sectional rather than longitudinal, hence, the impact of vulnerability on the long term growth performance of microeconomies is not considered (my emphasis). H. W. Armstrong and R. Read, 'The phantom of liberty? Economic growth and the vulnerability of micro-states', paper presented at the Conference on Small States in the International Economy, University of Birmingham, UK, April.

17 Remember the economic crisis of Newfoundland following the collapse of the fishery; the fiscal crisis of the Faroe Islands; the stock market collapse in South East Asia; ...

18 The Big 10 would be: China, India, USA, Indonesia, Brazil, Russia, Pakistan, Japan, Bangladesh and Nigeria. Total $=3420$ million people. The Smallest 10 would be: St Vincent and the Grenadines, Tonga, Grenada, Kiribati, Seychelles, Dominica, Antigua and Barbuda, St Kitts and Nevis, Tuvalu, and Nauru. Total = 650000 people. Data from United Nations Development Programme (UNDP), World Development Report 1997, United Nations, New York, 1998.

19 H. W. Armstrong, R. Jouan de Kervenoeal, X. Li and R. Read, 'A comparison of the economic performance of different micro-states and between micro-states and larger countries', World Development, Vol 26, No 4, 1998, pp 539-556.

20 'Little countries: small but perfectly formed', The Economist, 3 January 1998, pp 63-65. 
21 G. Baldacchino, 'Bursting the bubble: the pseudo-development strategies of micro-states', Development \& Change, Vol 24, No 1, 1993, pp 29-51.

22 T. I. J. Fairbairn, 'Indigenous entrepreneurship and business development in the Cook Islands', in Island Entrepreneurs: Problems and Performance in the Pacific, University of Hawaii Press, Hawaii, 1988, pp 55-76, especially p 75.

23 Commonwealth Secretariat, Overcoming Vulnerability: A Future for Small States, Commonwealth Secretariat, London, 1997, pp 29-30.

24 For example, A. J. Butter, An Introduction to Mini-Economics, B. R. Gruner Publishing, Amsterdam, 1985.

25 C. A. McRobie, Small is Possible, Cape, London, 1981; M. Max-Neef, From the Outside Looking In, Dag Hammarskjold Foundation, Uppsala, 1982.

26 R. Lamusse, 'Labour policy in the plantation islands', World Development, Vol 8, No 12, 1980, pp 1035-1050; Bray and Packer, op cit, Ref 3.

27 L. Pirandello, Six Characters in Search of an Author, translated by E. Storer, Dover, London, 1998.

H. W. Armstrong and R. Read, 'Trade and growth in small states: the impact of global trade liberalization', World Economy, Vol 21, No 4, 1998, pp 563-585; Armstrong and Read, op cit, Ref 16; G. Baldacchino, 'The other way round: manufacturing as an extension of services in small island states', Asia Pacific Viewpoint, Vol 39, No 3, 1998, pp 267-279; G. Baldacchino and D. Milne (eds), A Political Economy for Small Islands: The Resourcefulness of Jurisdiction, Macmillan, Basingstoke, 1999; D. Milne, Ten Lessons for Economic Development in Small Jurisdictions: the European Perspective, Institute of Island Studies, University of Prince Edward Island, Charlottetown, 1999.

29 E. Warrington, 'Introduction: Gulliver and Lilliput in a new world order: the impact of external relations in the domestic policies and institutions of microstates', Public Administration and Development, Vol 18, No 2, 1998, pp 101-105.

30 G. Baldacchino, 'The political economy of the edge: a novel approach to island studies', paper presented at the Vth World Congress of the International Small Island Studies Association, Mauritius, July 1998.

31 I. G. Bertram and R. F. Watters, 'The MIRAB economy in South Pacific microstates', Pacific View point, Vol 26, No 3, 1985, pp 497-519, especially p 499.

H. W. Armstrong and R. Read, 'Trade, competition and market structure in small states: the role of contestability', Malta, Bank of Valletta Review, No 18, 1998, pp 1-18.

33 Armstrong and Read, op cit, Ref 16.

34 J. D. Hache, 'Towards a political approach to the island question', in G. Baldacchino and R. Greenwood (eds), Competing Strategies of Socio-Economic Development for Small Islands, Institute of Island Studies, University of Prince Edward Island, Charlottetown, 1998, pp 31-68, especially p 54.

35 One must emphasise here that there are many possible constitutional variations of 'self-rule' or 'shared rule': these include unions, federations, confederations, federacies, associated states and condominiums. See D. J. Elazar (ed), Federal Systems of the World: A Handbook of Federal, Confederal \& Autonomy Relationships, 2nd edition, Longman, Harlow, Essex, 1994; R. L. Watts, Comparing Federal Systems in the 1990s, Institute for Intergovernmental Relations, Queen's University in association with McGill-Queen's University Press, Kingston, Ontario, 1996; R. L. Watts, 'Constitutional models for islands: a survey', in G. Baldacchino and D. Milne (eds), A Political Economy for Small Islands: The Resourcefulness of Jurisdiction, Macmillan, Basingstoke (forthcoming).

37 R. Hoefte and G. Oostindie, 'The Netherlands and the Dutch Caribbean: dilemmas 


\section{THE CHALLENGE OF HYPOTHERMIA}

of decolonization', in P. Sutton (ed), Europe and the Caribbean, Macmillan, London, 1990, pp 71-98.

38 Armstrong and Read, op cit, Ref 16.

39 Baldacchino, op cit, Ref 21; H. Kakazu, Sustainable Development of Small Island Economies, Westview Press, New York, 1994; Armstrong and Read, op cit, Ref 32 .

40 For example, L. M. Alexander, 'Centre and periphery: the case of island systems', in J. Gottmann (ed), Centre and Periphery, Sage Focus, London, 1980, pp 135-147.

41 Hache, op cit, Ref 34, pp 54-57.

42 For example, G. Baldacchino, Global Tourism and Informal Labour Relations: The Small Scale Syndrome at Work, Mansell, London, 1997; R. King, 'The geographical fascination of islands', in D. Drakakis-Smith, D. G. Lockhart and J. A. Schembri (eds), The Development Process in Small Island States, Routledge, London, 1993, pp 13-37; D. Pitt, 'Sociology, islands and boundaries', World Development, Vol 8, No 12, 1980, pp 1051-1059.

43 For example, S. Kuznets, 'Economic growth of small nations', in E. A. G. Robinson (ed), The Economic Consequences of the Size of Nations, Macmillan, London, 1960, pp 14-32, especially p 28; A. D. Knox, 'Some economic problems of small countries', in B. Benedict (ed), Problems of Smaller Territories, Athlone Press, London, 1967, pp 35-44, especially p 44; E. C. Dommen, 'Some distinguishing characteristics of island states', World Development, Vol 8, No 12, 1980, pp 931-944, especially p 942.

44 B. Benedict, 'Sociological aspects of smallness', in B. Benedict (ed), Problems of Smaller Territories, Athlone Press, London, 1967, pp 45-55; J. Richards, 'Politics in small independent communities: conflict or consensus?', Journal of Commonwealth \& Comparative Politics, Vol 20, No 2, 1982, pp 155-171, especially p 155; Butter, op cit, Ref 24, p 35; D. Lowentha1, 'Social features', in C. G. Clarke and A. Payne (eds), Politics, Development \& Security in Small States, Allen \& Unwin, London, 1987, pp 26-49, especially p 39.

45 Bray, op cit, Ref 3, p 26.

46 Baldacchino, op cit, Ref 42.

47 F. van Waarden, 'Employers and employers' associations', in J. Van Ruysseveldt, R. Huiskamp and J. van Hoof (eds), Comparative Industrial \& Employment Relations, Sage, London, 1995, pp 68-108, especially p 97.

48 P. Katzenstein, Small States in World Markets, Cornell University Press, Ithaca, NY, 1985.

49 R. A. Dahl and E. R. Tufte, Size and Democracy, Stanford University Press, Stanford, CA, 1973; Richards, op cit, Ref 44.

50 J. S. Coleman, Foundations of Social Theory, Belknap Press, London, 1990.

51 The Isle of Man's Tynwald is the oldest continuing legislative body in the Western World. Iceland's Althing is older but has an interrupted history. In the eastern hemisphere, the oldest legislature is that of Bermuda (1615), closely followed by that in Barbados.

52 E. Trist, 'The environment and system response capability', Futures, Vol 12, No 2, 1980, pp 113-127; G. Morgan, Riding the Waves of Change: Developing Managerial Competences for a Turbulent World, Jossey-Bass, San Francisco, CA, 1988; J. Chieuw, 'Smallness of scale: obstacle or opportunity? Reframing the issue of scale', in K. M. Lillis (ed), Policy, Planning \& Management of Education in Small States, UNESCO, Paris, 1993, pp 48-58.

53 T. R. Burns and A. M. Stalker, The Management of Innovation, Tavistock, London, 1984 (originally published in 1961). 
Malta and Mauritius were are the main examples here, with a manufacturing contribution to GDP exceeding 30 per cent in 1995. See Commonwealth Secretariat, Small States: Economic Review and Basic Statistics, Commonwealth Secretariat, London, 1996, Tables 3 and 26; Commonwealth Secretariat, op cit, Ref 23, Table 4.1 .

56 G. Hyden, No Shortcuts to Progress, Heinemann, London, 1983, p 60; J. J. Schahczenski, 'Development administration in the small developing state', in R. Baker (ed), Public Administration in Small and Island States, Kumarian Press, West Hertford, CT, 1992, pp 34-48, especially p 41.

57 This candid observation is attributed to Irish Prime Minister Bertie Ahern in explaining one of Ireland's advantages when it comes to exercising flexibility and rapid responsiveness in relation to the exigencies of potential foreign investors (personal communication).

58 The notion of 'economic capacity' is credited to participants at the Aspen Institute Planning Meeting on 'Economic Development in Plain English', November 1997, Queenstown, MA, USA.

59 Further research is needed to identify the diverse economic strategies entered into by different socioeconomic groups and classes of small islanders. Simply stating 'a people' or 'a community' is likely to discount internal differences and possible conflicts.

60 H. M. Hintjens, 'France in the Caribbean', in P. Sutton (ed), Europe and the Caribbean, Macmillan, London, 1991, pp 37-70.

61 The life histories of diverse microstate citizens, from Isaac Caines in St Kitts (B. C. Richardson, Caribbean Migrants: Environment and Human Survival on St Kitts \& Nevis, University of Tennessee Press, Knoxville, TN, 1983, pp 54-55) to Kawagl, a South Pacific Melanesian (H. C. Brookfield, Colonialism, Development and Independence: The Case of the Melanesian Islands in the South Pacific, Cambridge University Press, Cambridge, 1972, pp 167-168) to hotel employees in Malta and Barbados (Baldacchino, op cit, Ref 42, pp 126-128) readily demonstrate and flesh out such 'skills'.

62 T. Courchene, 'Glocalization: the regional/international interface', Canadian Journal of Regional Science/Revue Canadienne des Sciences Regionales, Vol 18, No 1, 1995, pp 1-20.

63 For example, G. Fischer and P. Encontrre, 'The economic disadvantages of island developing countries: problems of smallness, remoteness and economies of scale', in G. Baldacchino and R. Greenwood (eds), Competing Strategies of SocioEconomic Development for Small Islands, Institute of Island Studies, University of Prince Edward Island, Charlottetown, 1998, pp 69-85.

64 G. Baldacchino and R. Greenwood (eds), Competing Strategies of SocioEconomic Development for Small Islands, Institute of Island Studies, University of Prince Edward Island, Charlottetown, 1998.

65 See, for example, the 'special relationship' of the Isle of Man, Aaland, Faroe and Channel Islands-none of which are sovereign states-with the EU (N. Fagerlund, 'Autonomous European island regions enjoying a special relationship with the European Union', in L. Lyck (ed), Constitutionalism and Economic Space of the Small Nordic Jurisdictions, NordREFO, Copenhagen, 1997, pp 90-121).

66 The most successful here are probably the 'ultra peripheral regions' of the European Union, all of which (except French Guiana) are islands. These have now achieved an even stronger recognition of the permanence of their 'major structural backwardness' in Article 299 of the Treaty of Amsterdam. See Hache, op cit, Ref 34, pp 58, 65 . 